Western University Scholarship@Western

Centre for the Study of International Economic

Centre for the Study of International Economic

Relations Working Papers

Relations

1984

\title{
Equilibrium under Price Controls with Endogenous Transactions Costs
}

Trien Tien Nguyen

John Whalley

Follow this and additional works at: https://ir.lib.uwo.ca/economicscsier_wp

Part of the Economics Commons

Citation of this paper:

Nguyen, Trien Tien, John Whalley. "Equilibrium under Price Controls with Endogenous Transactions Costs." Centre for the Study of International Economic Relations Working Papers, 8433C. London, ON: Department of Economics, University of Western Ontario (1984). 
ISSN $\quad 0228-4235$

ISBN 0-7714-0573-1

CENTRE FOR THE STUDY OF INTERNATIONAL ECONOMIC RELATIONS

WORKING PAPER NO. $8433 C$

EOQUILIBRIUM UNDER PRICE CONTROLS WITH ENDOGENOUS

TRANSACTIONS COSTS

Depsrtment of Economics Library

Trien Tien Nguyen

and

SEP 191984

John Whalley

University of Western Ontario

This paper contains preliminary findings from research work still in progress and should not be quoted without prior approval of the author.

DEPARTMENT OF ECONOMICS

UNIVERSITY OF WESTERN ONTARIO

LONDON, CANADA

N6A 5 C 2 


\title{
EQUILIBRIUM UNDER PRICE CONTROLS WITH ENDOGENOUS TRANSACTIONS COSTS
}

\author{
Trien Tien Nguyen \\ Department of Economics \\ University of Waterloo \\ Waterloo, Ontario, Canada N2L 3G1 \\ John Whalley + \\ Department of Economics \\ The University of Western Ontario \\ London, Ontario, Canada N6A 5C2
}

August 1984 (revised)

Department of Economics Library

$$
\text { SEP } 191984
$$

Universily of Westem Ontario

+ We are grateful to G. van der Laan and Bernd Koch for helpful comments. The Social Sciences and Humanities Research Council of Canada has provided for financial support. 
This paper presents both an existence proof and numerical computations of equilibria in which endogenous transactions (or search) costs are determined in response to government legislated fixed relative prices. Price controls may apply to all commodities or only a subset of commodities. Real resources are involved with the equilibrating process as buyers attempt to locate sellers (or vice versa) at fixed prices. The larger the excess demand (or supply) in any market, the costlier it becomes to locate a transactor on the other side of the market. This formulation of real resource costs involved in equilibrating markets under price controls is related to Krueger's [6] well-known formulation of equilibrium under quantity controls where resources used in rent-seeking activities are part of the equilibrating process.

Our aim is eventual empirical application of this equilibrium concept directed towards an evaluation of the welfare costs of distortions induced by economy-wide wage and price controls. Most existing empirical literature on these controls focus on their macroeconomic impacts on inflation, unemployment, and other macro variables. This contrasts with the main attack on these controls from Friedman and others which is usually on resource allocation grounds.

Rather than model an economy with a given transactions technology, we allow transactions (search) costs to be endogenously determined. The parable is that in an economy with price controls, the larger the divergence between controlled and marketclearing prices, the costlier it becomes for sellers and buyers to locate each other. The differentials that these costs generate between effective buying and selling prices (including search costs) are endogenously determined so as to clear markets, and also provide the major part of the social costs of price controls. These equilibria are also equivalent to a formulation in which proportional rationing accompanies the constrained side of any market. Previous literature on the theory of distortions has not provided a general equilibrium formulation for investigating the resource allocation effects of government-controlled prices. This is what we attempt here. 
Our work contrasts with the literature on fixed price equilibria generated by Drèze [2] and Benassy [1] which uses a quite different quantity rationing formulation as an equilibrating mechanism for resource allocation when prices are institutionally rigid. Developments within this literature have been mainly concerned with the formal characterization of these fixed price equilibria (including existence) and their relationship to Keynesian macroeconomics (e.g., Grandmont and Laroque [3]) rather than with an evaluation of the welfare effects of price controls. In our analysis prices are fixed by government fiat, as is the case of a system of economy-wide wage and price controls, instead of simply being sticky. Some of the recent computationally oriented models of fixed price equilibria such as Imam and Whalley [4], Kehoe and Serra-Puche [5], Nguyen [7], Reif [8], and van der Laan [12] have also been moving in this direction.

The plan of the paper is as follows: section 1 sets out the basic framework of an exchange economy with fixed prices and endogenously-determined transactions costs. Section 2 outlines an existence proof of an equilibrium with endogenously-determined transactions costs and market demands under exogenously-fixed relative prices. The mapping used in the existence proof also allows for any variant of the well-known fixedpoint algorithms to be used to compute such an equilibrium. Section 3 provides some simple numerical examples using such computational procedures. Section 4 concludes the paper with some remarks on potential applications and further extensions of the model.

\section{THE BASIC FRAMEWORK}

We consider a pure exchange economy with $m$ agents $(i=1, \ldots, m)$ and $n$ goods $(j=1, \ldots, n)$. All prices are exogenously fixed by government decrees at positive non-market clearing levels $\mathbf{p}=\left(p_{1}, \ldots, p_{n}\right)>0$. For simplicity we assume that each agent $i$ has a positive vec- 
tor of initial endowments $w^{i}=\left(w_{1}{ }^{i}, \ldots, w_{n}{ }^{i}\right)>0$. For each good $j$ there are endogenouslydetermined search costs which produce buying prices (gross of search costs) $\mathrm{p}_{j} \mathbf{b}^{\mathbf{b}} \geq \mathrm{p}_{\mathrm{j}}$ and selling prices (net of search costs) $\mathrm{p}_{\mathrm{j}}{ }^{\mathrm{s}} \leq \mathrm{p}_{\mathrm{j}}$. In equilibrium these prices will 'clear' markets. Only one side of each market can be rationed since either excess demands or excess supplies, but not both, can occur simultaneously in any market under price controls. Thus either $p_{j}^{b}=p_{j}$ or $p_{j}{ }^{s}=p_{j}$ or both conditions hold for each $j$. We denote the vector of prices received by the seller by $\mathbf{p}^{\mathbf{s}}$ and the vector of prices paid by buyers as $\mathbf{p}^{\mathbf{b}}$. Any differences from the controlled prices $\mathbf{p}$ are accounted for solely by the search costs involved.

In this model, equilibrium rationing involves real resource costs devoted to transacting, which increases as transacting becomes more costly. A parable for such equilibria is that real resources are expended as buyers or sellers on the constrained side of each market locate agents with whom they can transact, with the constrained side of the market bearing the costs involved. These search costs represent endogenouslydetermined transactions costs, in contrast to the fixed transactions technology approach of ten employed in the literature on general equilibrium in the presence of transactions costs. We could have complicated our model by explicitly representing the search technology as one of repeated trials, each involving an attempt to find an agent with whom one can transact at the fixed prices. With a fixed resource cost per trial, the number of trials would be endogenously determined yielding an equivalent but more complex version of the same formulation used here. The resource costs of transacting are an important ingredient of the model, since they become a major component of the welfare costs associated with price controls ${ }^{1}$

Two different formulations of our model are possible: one where endogenous transactions costs are associated with making net trades (demands less endowments) and one where costs accrue from making gross trades. The gross trade case is analytically and computationally simpler, the net trade case is slightly more complex. 
In the case where transactions costs are associated with gross trades, the demand side of the economy is characterized by a set of continuous nonnegative market demand functions of these market buying and selling prices $x_{j}=x_{j}\left(p^{b}, p^{s}\right)$ for $j=1, \ldots, n$. The $x_{j}$ are homogeneous of degree zero with respect to $\left(\mathbf{p}^{\mathbf{b}}, \mathbf{p}^{\mathbf{s}}\right)$ and satisfy a version of Walras law stated as

$$
\Sigma_{j} p_{j}^{b} x_{j}=\Sigma_{j} p_{j}^{s} w_{j}
$$

where aggregate initial endowments $w_{j}(j=1, \ldots, n)$ equal the sum of individual initial endowments

$$
w_{j}=\Sigma_{i} w_{j}^{i} \text {. }
$$

Search (transactions) costs are assumed to be borne exclusively by the constrained side of any market, and involve a real resource cost denoted in units of that commodity. The search costs involved in selling a unit of commodity $j$ at the price $\mathrm{p}_{j}$ are $\left(p_{j}-p_{j}{ }^{S}\right) / p_{j}$ and search costs for buyers purchasing at the price $p_{j}$ are $\left(p_{j} b-p_{j}\right) / p_{j}$. This formulation models search costs as $\left(p_{j}-p_{j}{ }^{5}\right)$ per dollars of sales at prices $p_{j}$ and $\left(p_{j}^{b}-p_{j}\right)$ per dollars of purchases at prices $p_{j}$.

Since search costs in any market are measured in terms of the commodity traded, we can write market demand functions different from those in the more traditional Arrow-Debreu pure exchange general equilibrium model by including search costs on the demand and supply sides of each market. These are written as

$$
z_{j}=\left(p_{j} b^{b} / p_{j}\right) x_{j}-\left(p_{j} s / p_{j}\right) w_{j}
$$

$(j=1, \ldots, n)$ where $\left(p_{j}{ }^{b} / p_{j}\right) x_{j}$ denote the total demands (including buyers' search costs) for final demands $x_{j}$ given buying and controlled prices $p_{j}{ }^{b}, p_{j}$ and $\left(p_{j} s / p_{j}\right) w_{j}$ denote the net supplies (after sellers' search costs) given selling and controlled prices $\mathrm{p}_{\mathbf{j}} \mathbf{s}^{\mathbf{s}}, \mathrm{p}_{\mathbf{j}}$. 
We can rewrite Walras law (1) as

$$
\Sigma_{j} p_{j} x_{j}=\Sigma_{j} p_{j} w_{j}-T
$$

where

$$
T=\Sigma_{j}\left(p_{j}^{b}-p_{j}\right) x_{j}+\Sigma_{j}\left(p_{j}-p_{j}{ }^{s}\right) w_{j}
$$

denotes the total transactions costs. Walras law then implies that $\Sigma_{\mathbf{j}} \mathrm{p}_{\mathbf{j}} \mathbf{z}_{\mathbf{j}}=0$. If there are no transactions costs (i.e., $p_{j}{ }^{b}=p_{j}{ }^{s}=p_{j}$ for all $j=1, \ldots, n$ ) then Walras law (4) degenerates to the more usual form

$$
\Sigma_{j} p_{j} x_{j}=\Sigma_{j} p_{j} w_{j}
$$

With this framework stated, an equilibrium can be defined as vectors of buying and selling prices $\left(\mathbf{p}^{b^{*}}, \mathbf{p}^{\mathbf{s}^{*}}\right)$ and market demands $\mathbf{x}^{*}=\mathbf{x}^{*}\left(\mathbf{p}^{b^{*}}, \mathbf{p}^{\mathbf{s}^{*}}\right)$ such that for $\mathrm{j}=1, \ldots, \mathrm{n}$

$$
\begin{gathered}
z_{j}=\left(p_{j} b^{*} / p_{j}\right) x_{j}^{*}-\left(p_{j} s^{*} / p_{j}\right) w_{j}=0, \\
\text { either } p_{j}^{b^{*}}=p_{j}, 0 \leq p_{j}{ }^{*} \leq p_{j} \text { or } p_{j} s^{*}=p_{j}, p_{j} \leq p_{j} b^{*} .
\end{gathered}
$$

Condition (6) clears all markets in the sense that the market demand for any good $j$, including any transactions costs on the demand side, is equal to the supply of that good after sellers' transactions costs. A strict equality rather than the more usual demandsupply inequality characterizes equilibrium since strict positivity of controlled (and hence buying) prices is assumed. Condition (7) requires that only one side of any market bears transactions costs. In no markets do both buyers and sellers of the same good bear transactions costs at the same time. This one-side-of-market condition makes this concept of equilibrium a nontrivial extension of the traditional Arrow-Debreu theory of competitive equilibrium. 
In the case where transactions costs are associated with making net trades the budget constraint for any agent $i$ is written as

$$
\Sigma_{j} p_{j}^{b} \max \left(x_{j}{ }^{i}-w_{j}{ }^{i}, 0\right)=\Sigma_{j} p_{j}^{s} \max \left(w_{j}{ }^{i}-x_{j}{ }^{i}, 0\right) .
$$

Market demands $x_{j}$ equal the sum of individual demands $\Sigma_{i} x_{j}^{i}$ and Walras law in this case is written as in (4)

$$
\Sigma_{j} p_{j} x_{j}=\Sigma_{j} p_{j} w_{j}-T
$$

but now

$$
T=\Sigma_{i} \Sigma_{j}\left(p_{j}^{b}-p_{j}\right) \max \left(x_{j}{ }^{i}-w_{j}{ }^{i}, 0\right)+\Sigma_{i} \Sigma_{j}\left(p_{j}-p_{j}{ }^{s}\right) \max \left(w_{j}{ }^{i}-x_{j}{ }^{i}, 0\right) .
$$

Equilibrium is defined by vectors of buying and selling prices $\left(\mathbf{p}^{\mathrm{b}^{*}}, \mathrm{p}^{\mathbf{s}^{*}}\right.$ ) and market demands $x^{*}=x^{*}\left(\mathbf{p}^{b^{*}}, \mathbf{p}^{s^{*}}\right)$ such that for $j=1, \ldots, n$

$$
\begin{gathered}
z_{j}=x_{j}^{*}-w_{j}-\zeta_{j}=0 \\
\text { either } p_{j}^{b^{*}}=p_{j}, 0 \leq p_{j}{ }^{*} \leq p_{j} \text { or } p_{j}{ }^{*}=p_{j}, p_{j} \leq p_{j} b^{*}
\end{gathered}
$$

where the additional terms

$$
\zeta_{j}=\Sigma_{i}\left\{\left(p_{j} b^{*}-p_{j}\right) / p_{j}\right\} \max \left(x_{j}{ }^{i^{*}}-w_{j}{ }^{i}, 0\right)+\Sigma_{i}\left\{\left(p_{j}-p_{j}{ }^{*}\right) / p_{j}\right\} \min \left(w_{j}{ }_{j}-x_{j}{ }^{i *}, 0\right)
$$

$(j=1, \ldots, n)$ in the demand supply equalities in this case reflect the endogenouslydetermined transactions costs denominated in units of the commodity traded. These terms are more complicated than in the case of transactions costs associated with gross trades. 


\section{EXISTENCE AND COMPUTATION OF EQUILIBRIA}

In this section we provide an existence proof for equilibrium under fixed prices and endogenous transactions costs. The mapping constructed can also be used in a computational procedure to find such an equilibrium.

We consider a standard (n-1)-dimensional unit simplex $S$, and normalize the positive vector $\mathbf{p}$ of fixed prices so that $\mathbf{p}$ belongs to the interior of $\mathbf{S}$. We define vectors of buying and selling prices $\left(\mathbf{p}^{b}, \mathbf{p}^{\mathbf{s}}\right)$ in terms of elements $\mathbf{s}$ of $\mathbf{S}$ as follows:

$$
\begin{aligned}
& p_{j}^{b}=\max \left(p_{j}, s_{j}\right) \geq p_{j}, \\
& p_{j}{ }^{s}=\min \left(p_{j}, s_{j}\right) \leq p_{j},
\end{aligned}
$$

$(j=1, \ldots, n)$. This construction allows us to redefine the commodity demand functions in either the gross trade or net trade case as

$$
x_{j}=x_{j}\left(p^{b}, p^{s}\right)=x_{j}(s)
$$

$(j=1, \ldots, n)$ and the market excess demand functions [either ( 3$)$ or $(10)]$ as

$$
\mathbf{z}_{\mathbf{j}}=\mathbf{z}_{\mathbf{j}}(\mathbf{s})
$$

$(j=1, \ldots, n)$. Since $\left(\mathbf{p}^{\mathbf{b}}, \mathbf{p}^{\mathbf{s}}\right)$ are continuous functions of $s$, so are commodity demands $x=$ $\left(x_{1}, \ldots, x_{n}\right)$ and excess demands $z=\left(z_{1}, \ldots, z_{n}\right)$. We next consider a variant of Gale-Nikaido mapping $\mathbf{G}: \mathbf{S} \rightarrow \mathbf{S}$

$$
G_{\mathbf{j}}(\mathbf{s})=\left\{\mathbf{s}_{\mathbf{j}}+\max \left(\mathbf{z}_{\mathbf{j}}(\mathbf{s}), 0\right)\right\} /(1+\Delta)
$$

$(j=1, \ldots, n)$ where

$$
\Delta=\Sigma_{j} \max \left(\mathbf{z}_{j}(\mathbf{s}), 0\right)
$$


$\mathbf{G}$ is clearly a continuous mapping of the standard unit simplex $\mathbf{S}$ into itself. Brouwer's fixed-point theorem then applies: there exists a fixed point $s^{*}$ in $S$ such that $s^{*}=G\left(s^{*}\right)$. Let $\left(\mathbf{p}^{\mathrm{b}^{*}}, \mathbf{p}^{\mathbf{s}^{*}}\right)$ and $\left(\mathbf{x}^{*}, \mathbf{z}^{*}\right)$ be determined by the fixed point $\mathbf{s}^{*}$ according to Eqs. (12)-(15). It remains to show that $\left(\mathbf{p}^{\mathbf{b}^{*}}, \mathbf{p}^{\mathbf{s}^{*}}\right)$ and $\left(\mathbf{x}^{*}, \mathbf{z}^{*}\right)$ satisfy equilibrium conditions $(6,7)[$ or $(10,11)]$.

- The one-side-of-market condition (7) [or (11)] is clearly satisfied through the constructions $(12,13)$.

- To check the market-clearing condition (6) [or (10)] we rewrite (16) as follows:

$$
\Delta s_{j}^{*}=\max \left(z_{j}^{*}, 0\right)
$$

$(j=1, \ldots, n)$. Suppose $z_{j}{ }^{*}>0$ for at least one $j$. This implies $\Delta>0$ and $s_{j}^{*}>0$ which in turn implies $\mathrm{p}_{\mathrm{j}} \mathrm{b}^{*}>0$ and $\mathrm{p}_{\mathrm{j}} \mathrm{s}^{*}>0$. If $\mathrm{z}_{\mathrm{k}}{ }^{*}<0$ for at least one $\mathrm{k} \neq \mathrm{j}$, then the positivity of $\Delta$ [from (18)] implies that $s_{k}{ }^{*}=0$. This in turn implies that $\mathrm{p}_{k} \mathrm{~s}^{*}=0$. From (6) [or (10)], however, $\mathrm{p}_{\mathrm{k}} \mathrm{s}^{*}=0$ contradicts the negativity of $\mathrm{z}_{\mathrm{k}}{ }^{*}$. Thus if $\mathrm{z}_{\mathrm{j}}{ }^{*}$ $>0$ then $z_{k}^{*} \geq 0$ for all $k \neq j$. Walras law (4) [or (9)] implies that $\Sigma_{j} p_{j} z_{j}^{*}=0$. The strict positivity of $\mathrm{p}_{j}$ therefore implies that $\mathrm{z}_{j}{ }^{*}$ must equal to zero for all $\mathrm{j}$. This implies that market clearing condition (6) [or (10)] must hold, and that an equilibrium exists in either the gross or net trade.

This same mapping $\mathbf{G}$ of the standard unit simplex $\mathbf{S}$ into itself can also be used to compute the equilibrium values of buying and selling prices, and market demands, given any set of fixed prices in either the gross or net trade case. Any one of the available fixed-point algorithms, such as Scarf [9] or the subsequent refinement due to van der Laan and Talman $[10,11]$ can be adopted for this purpose. Extending this difficulty in approach to incorporate production seems to be relatively straightforward. Although Imam and Whalley [4] have recently noted that for a model in which price ceilings or 
floors are maintained by some government intervention schemes it is possible to construct an activity which will always make positive profits given the ceilings or floors, this issues does not arise with the present formulation due to the endogeneity of buying and selling prices.

\section{A SIMPLE NUMERICAL EXAMPLE}

To illustrate our approach we have computed a series of simple numerical examples of equilibria in the presence of government controlled prices where endogenous transactions costs are associated with gross rather than net trades. This case is simpler to code the computer program and serves to illustrate our approach, although transactions costs will be larger when associated with gross rather than net trades. The functions and parameter values used are arbitrarily chosen; in an application to practical policy situations they would clearly need to be more carefully specified.

We consider a pure exchange economy with 5 commodities and 6 consumers. Individual initial endowments are given by

\section{Commodity}

$\begin{array}{ccccccc} & 1 & 2 & 3 & 4 & 5 & 6 \\ 1 & 20 & 5 & 10 & 10 & 5 & 44 \\ 2 & 5 & 10 & 10 & 10 & 2 & 21 \\ 3 & 10 & 10 & 30 & 5 & 3 & 6 \\ 4 & 5 & 10 & 10 & 3 & 5 & 30 \\ 5 & 4 & 10 & 4 & 1 & 20 & 1\end{array}$

We assume Cobb-Douglas preference functions for each consumer with the following preference parameters 
Commodity

$\begin{array}{ccccccc} & 1 & 2 & 3 & 4 & 5 & 6 \\ 1 & 0.143 & 0.200 & 0.428 & 0.143 & 0.143 & 0.143 \\ 2 & 0.143 & 0.200 & 0.143 & 0.428 & 0.143 & 0.143 \\ 3 & 0.428 & 0.200 & 0.143 & 0.143 & 0.143 & 0.143 \\ 4 & 0.143 & 0.200 & 0.143 & 0.143 & 0.143 & 0.428 \\ 5 & 0.143 & 0.200 & 0.143 & 0.143 & 0.428 & 0.143\end{array}$

A competitive equilibrium price vector for this economy in the absence of price controls is given by the normalized price vector $(0.1332,0.1812,0.1752,0.2242,0.2862)$. If the controlled price vector $(0.10,0.18,0.15,0.25,0.32)$ is considered, the equilibrium buying and selling prices are

Commodity

1
2
3
4
5

Buying Prices

0.34
0.18
0.15
0.25
0.32

Selling Prices

0.10
0.14
0.13
0.17
0.22
Fixed Prices

$$
\begin{aligned}
& 0.10 \\
& 0.18 \\
& 0.15 \\
& 0.25 \\
& 0.32
\end{aligned}
$$

Market excess demands are all less than 0.002 in absolute value for a grid size of 100,000 in computation. Execution costs are small. Welfare losses from price controls in terms of Hicksian equivalent variations (EV) and compensating variations (CV) are $38.8 \%$ and $45.8 \%$ of national income ${ }^{2}$, respectively.

In further examples we have considered sequences of cases in which the controlled prices asymptotically approach the competitive equilibrium prices. We have used CES preferences with the same Cobb-Douglas share parameters above and the following elasticities of substitution

Consumer

\begin{tabular}{cclccc}
1 & 2 & \multicolumn{1}{c}{3} & 4 & 5 & 6 \\
100 & 0.200 & 0.250 & 0.400 & 0.500 & 0.800 \\
325 & 0.400 & 0.4375 & 0.550 & 0.625 & 0.850 \\
550 & 0.600 & 0.625 & 0.700 & 0.750 & 0.900 \\
775 & 0.800 & 0.8125 & 0.850 & 0.875 & 0.950
\end{tabular}


We have computed the economy-wide welfare losses from price controls in terms of the arithmetic sum of EV's across individual consumers which, not surprisingly, monotonically falls as the controlled prices approach the competitive equilibrium prices (see Figure 1). We allow for this by initially fixing the controlled prices at the barycenter of the unit simplex, computing the welfare loss, and then allowing the controlled prices to approximate the competitive equilibrium prices by taking them to be alternative distances along the line segment connecting the barycenter and the competitive equilibrium prices. In each case, the welfare losses of fixing prices at the barycenter of the unit simplex are

EV as \% of National Income

$\begin{array}{lll}\text { Case } 1 & 72.2 & 0.325 \\ \text { Case 2 } & 67.1 & 0.234 \\ \text { Case 3 } & 59.6 & 0.179 \\ \text { Case 4 } & 51.2 & 0.141 \\ \text { Cobb-Douglas } & 42.3 & 0.116\end{array}$

\section{Euclidean Distance From Competitive Price Vector to the Barycenter}

0.325

0.179

0.116

These large welfare costs reflect the endogenously-determined resource costs of the search activity involved although as we have noted above, the assumption of gross rather than net trades involved in transactions costs produces larger welfare cost estimates. While these calculations are not realistic representations of actual economies, the calculations are suggestive that welfare costs associated with fixed price equilibria may be much larger than the commonly measured costs of ad valorem tax and other distortions. These simple numerical examples thus demonstrate the applicability of the approach and its potential value for future policy evaluation work. 


\section{CONCLUSION}

In this paper we have presented an equilibrium model for an exchange economy with fixed prices and endogenously-determined search or transactions costs. Given the fixed prices, endogenously-determined equilibrium buying and selling prices (which include transactions costs) result. These costs occur on either the demand or supply side of each market, but not both. We see an eventual application of this approach to an evaluation of welfare costs of economy-wide wage and price controls, and to sector-specific price controls such as energy. In the final section we present some simple numerical examples which illustrate the approach. 


\section{FIGURE 1 .}

\section{WELFARE LOSSES}

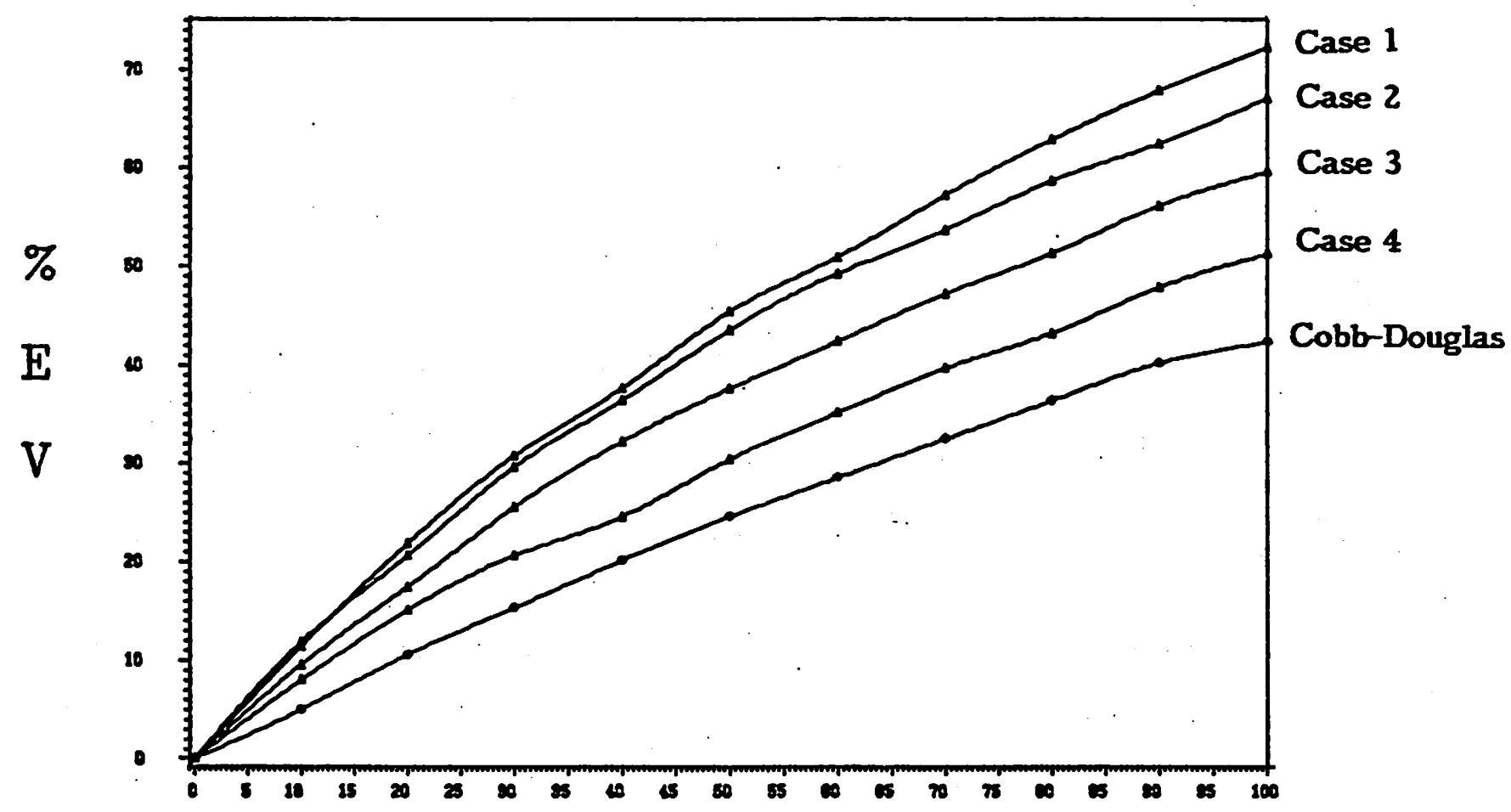

COMPETITIVE EQUILIBRIUM (0\%) TO BARYCENTER (100\%) 


\section{NOTES}

1. An alternative version of our model (not presented here) centers on a costless government agency which reallocates untraded commodities in a lump sum fashion once equilibrium is achieved. This income transfer model which involves endogenously-determined rationing proportions but no real resource costs in transacting at fixed prices, is discussed in [7].

2. National income is defined as the value of aggregate endowments at competitive equilibrium prices. 


\section{REFERENCES}

1. J. P. Benassy, "Neo-Keynesian Disequilibrium Theory in a Monetary Economy," Rev. Econ. Studies 42 (1975), 503-523.

2. J. H. Drèze, "Existence of an Exchange Equilibrium Under Price Rigidities," Internat. Econ. Rev. 16 (1975), 301-320.

3. J. M. Grandmont and G. Laroque, "On Temporary Keynesian Equilibrium," Rev. Econ. Studies 43 (1976), 53-67.

4. H. Imam and J. Whalley, "General Equilibrium with Price Intervention Policies: A Computational Approach," J. Pub. Econ. 18 (1982), 105-119.

5. T. J. Kehoe and J. Serra-Puche, "A Computational General Equilibrium Model with Endogenous Unemployment - An Analysis of the 1980 Fiscal Reform in Mexico," J. Pub. Econ. 22 (1983), 1-26.

6. A. O. Krueger, "The Political Economy of the Rent-Seeking Economy," Amer. Econ. Rev. 64 (1974), 291-303.

7. T. T. Nguyen, "General Equilibrium Under Price Controls," Ph. D. Dissertation, University of Western Ontario, September, 1981.

8. N. Reif, A Disaggregate Model of Applied Disequilibrium Theory, Oelgeschlager, Gunn \& Hain, Cambridge, Mass. (1981).

9. H. E. Scarf (with the collaboration of T. Hansen), The Computation of Economic Equilibria, Yale University Press, New Haven (1973).

10. A. J. J. Talman, Variable Dimension Fixed Point Algorithm and Triangulations, Vrije Universiteit Amsterdam, Amsterdam (1980).

11. G. van der Laan, Simplicial Fixed Point Algorithms, Vrije Universiteit Amsterdam, Amsterdam (1980).

12. G. van der Laan, "Simplicial Approximation of Unemployment Equilibria," J. Math. Econ. 9 (1982), 83-97. 


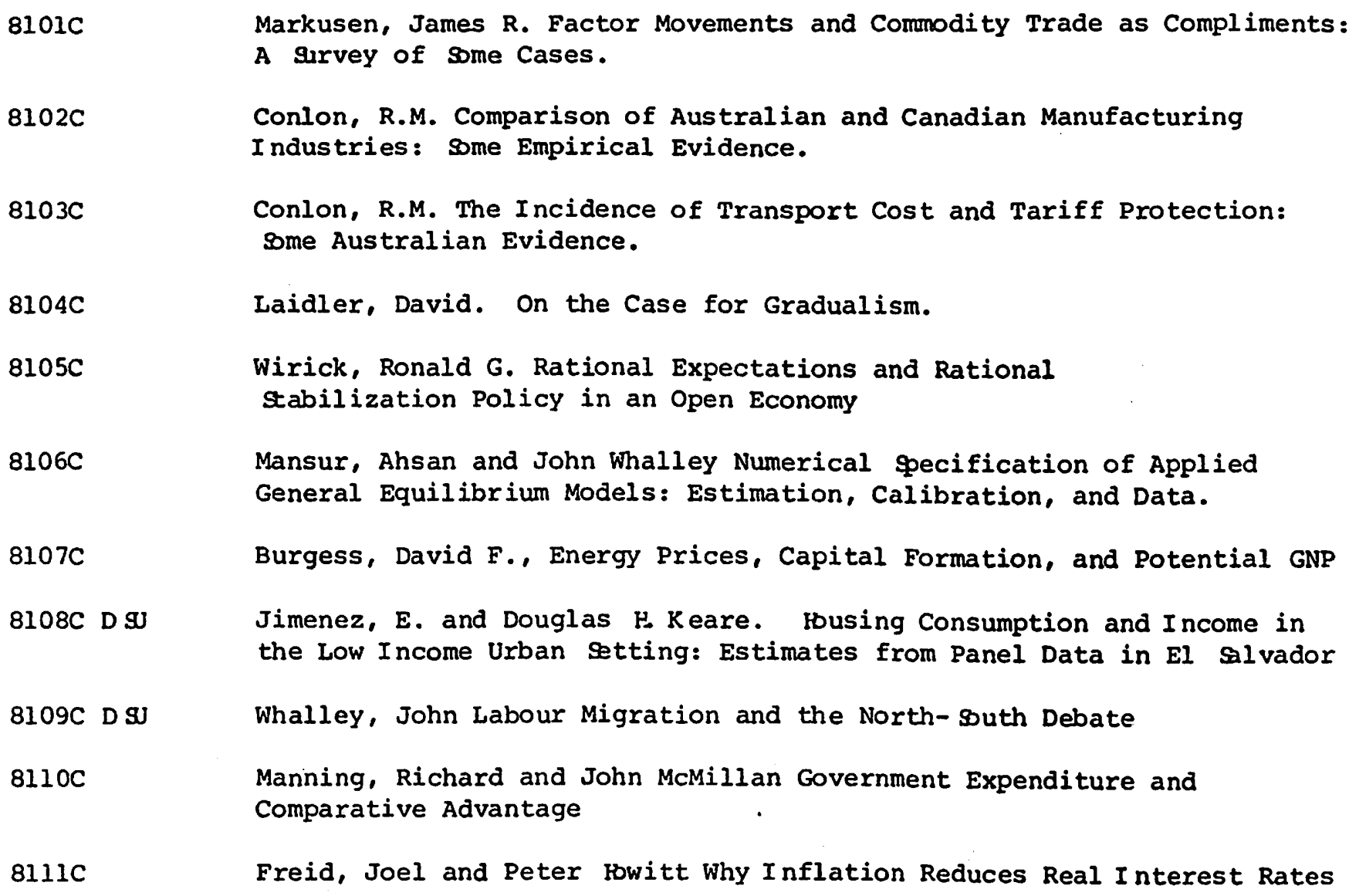

Markusen, James R. Factor Movements and Commodity Trade as Compliments: A Survey of Some Cases.

Conlon, R.M. Comparison of Australian and Canadian Manufacturing Industries: Some Empirical Evidence.

Conlon, R.M. The Incidence of Transport Cost and Tariff Protection: Some Australian Evidence.

Laidler, David. On the Case for Gradualism.

Wirick, Ronald G. Rational Expectations and Rational Stabilization Policy in an Open Economy

Mansur, Ahsan and John Whalley Numerical secification of Applied General Equilibrium Models: Estimation, Calibration, and Data.

Burgess, David F., Energy Prices, Capital Formation, and Potential GNP

Jimenez, E. and Douglas H Keare. Husing Consumption and Income in the Low Income Urban Setting: Estimates from Panel Data in El salvador

Whalley, John Labour Migration and the North-South Debate

Manning, Richard and John McMillan Government Expenditure and Comparative Advantage

Freid, Joel and Peter fowitt Why Inflation Reduces Real Interest Rates

$\underline{1982}$

Manning, Richard and James R. Markusen Dynamic Non-Substitution and Long Run Production Possibilities

Feenstra, Robert and Ken Judd Tariffs, Technology Transfer, and Welfare

Ronald $W$. Jones, and Douglas D. Purvis: International Differences in Response to Common External Shocks: The Role of Purchasing Power Parity

James A Brander and Barbara J. \$pencer: Industrial strategy with Committed Firms

Whalley, John, The North-South Debate and the Terms of Trade: An Applied General Equilibrium Approach

Roger Betancourt, Christopher Clague, Arvind Panagariya CAPI TAL UTT LIZATI ON IN GENERAL ERUILIBRIUM

Mansur, Ahsan $H$, On the Estimation of Import and Export Demand Elasticities and Elasticity Pessimism.

Whalley, J. and Randy Wigle PRICE AND QUANTITY RIGIDITIES IN ADJUSTMENT TO TRADE POLICY CHANGES: ALTERNATIVE FORMULATIONS AND INITIAL CALCULATIONS

Jimenez, E. SQUATTING AND COMMUNITY ORGANIZATION IN DEVELOPING COUNTRIES: A CONCEPTUAL FRAMEWORK 
8210C Grossman, G.M. INTERNATIONAL COMPETITION AND THE UNIONIZED SECTOR

8211C Laidler,D. FRIEDMAN AND SCHWARTZ ON MONETARY TRENDS - A REVIEW ARTICLE

8212C Imam, M.H. and Whalley, J. INCIDENCE ANALYSIS OF A SECTOR SPECIFIC MINIMUM WAGE IN A TWO SECTOR HARRIS-TODARO MODEL.

8213C Markusen, J.R. and Melvin, J.R. THE GAINS FROM TRADE THEOREM WITH INCREASING
RETURNS TO SCALE.

8214C INDUSTRIAL ORGANIZATION AND THE GENERAL EQUILIBRIUM COSTS OF PROTECTION IN
SMALL OPEN ECONOMIES.

8215C Laidler, D. DID MACROECONOMICS NEED THE RATIONAL EXPECTATIONS REVOLUTION?

8216C Whalley, J, and Wigle, R. ARE DEVELOPED COUNTRY MULTILATERAL TARIFF REDUCTIONS NECESSARILY BENEFICIAL FOR THE U.S.?

8217C Bade, R. and Parkin, M. IS STERLING M3 THE RIGHT AGGREGATE?

8218C Kosch, B. FIXED PRICE EQUIIIBRIA IN OPEN ECONOMIES.

$\underline{1983}$

8301C Kimbel1, L.J. and Harrison, G.W. ON THE SOLUTION OF GENERAL EQUILIBRIUM
MODELS.

8302C Melvin, J.R. A GENERAL EQUUILIBRIUM ANALYSIS OF'.CANADIAN OIL POLICY.

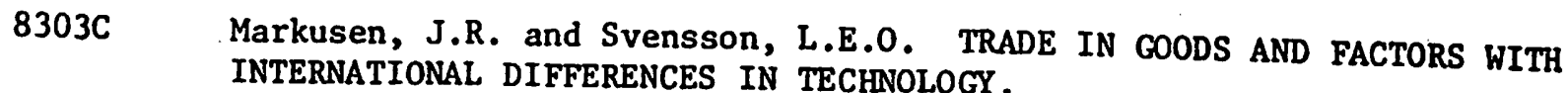

8304C Mohammad, S. Whalley, J. RENT SEEKING IN INDIA: ITS COSTS AND POLICY
SIGNIFICANCE.

8305C DSU Jimenez, E. TENURE SECURITY AND URBAN SQUUATING.

8306C Parkin, M. WHAT CAN MACROECONOMIC THEORY TELL US ABOUT THE WAY DEFICITS
SHOULD BE MEASURED.

8307C Parkin, M. THE INFLATION DEBATE: AN ATTEMPT TO CLEAR THE AIR.

$8308 \mathrm{C}$ Wooton, I. LABOUR MIGRATION IN A MODEL OF NORTH-SOUTH TRADE.

$8309 \mathrm{C}$ Deardorff, A.V. THE DIRECTIONS OF DEVELOPING COUNTRIES TRADE: EXAMPLES
FROM PURE THEORY. 8310C Manning, R. ADVANTAGEOUS REALLOCATIONS AND MULTIPLE EQUILIBRIA: RESULTS
FOR THE THREE-AGENT TRANSFER PROBLEM. 


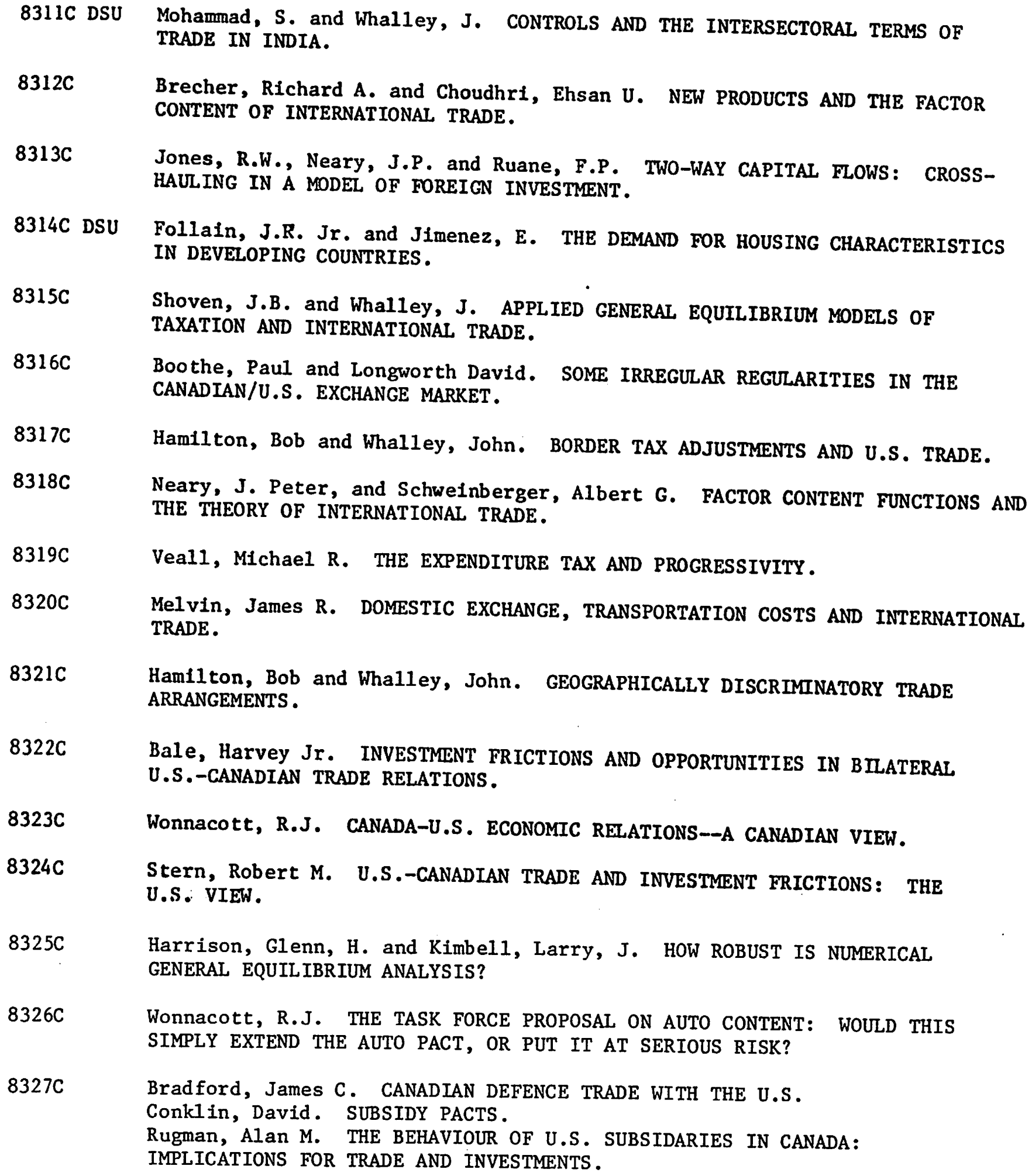


8328C Boyer, Kenneth D. U.S.-CANADIAN TRANSPORTATION ISSUES.

8329C Bird, Richard $M$. and Brean, Donald J.S. CANADA-U.S. TAX RELATIONS: ISSUES AND PERSPECTIVES.

8330C Moroz, Andrew R. CANADA-UNITED STATES AUTOMOTIVE TRADE AND TRADE POLICY ISSUES.

8331C Grey, Rodney de C. and Curtis, John. INSTITUTIONAL ARRANGEMENTS FOR U.S.-CANADIAN NEGOTIATIONS. PART I: CANADA-U.S. TRADE AND ECONOMIC ISSUES: DO WE NEED A NEW INSTITUTION? PART II: INSTITUTIONAL ARRANGEMENTS FOR MANAGING THE CANADA-U.S. ECONOMIC RELATIONSHIP.

\section{4}

8401C Harrison, Glenn $w$. and Manning, Richard. BEST APPROXIMATE AGGREGATION OF INPUT-OUTPUT SYSTEMS.

8402C Parkin, Michael. CORE INFLATION: A REVIEW ESSAY.

8403C Blomqvist, Ảke, and McMahon, Gary. SIMULATING COMMERICAL POLICY IN A SMALL, OPEN DUAL ECONOMY WITH URBAN UNEMPLOYMENT: A GENERAL EQUILIBRIUM APPROACH.

8404C Wonnacott, Ronald. THE THEORY OF TRADE DISCRIMINATION: THE MIRROR IMAGE OF VINERIAN PREFERENCE THEORY?

8405C Whalley, John. IMPACTS OF A 50\% TARIFF REDUCTION IN AN EIGHT-REGION GLOBAL TRADE MODEL.

8406C Harrison, Glenn W. A GENERAL EQUILIBRIUM ANALYSIS OF TARIFr REDUCTIONS.

8407C Horstmann, Ignatius and Markusen, James R. STRATEGIC INVESTMENTS AND THE DEVELOPMENT OF MULTINATIONALS.

8408C Gregory, Allan W. and McCurdy, Thomas H. TESTING THE UNBIASEDNESS HYPOTHESIS IN THE FORWARD FOREIGN EXCHANGE MARKET: A SPECIFICATION ANALYSIS .

$8409 \mathrm{C} J o n e s$, Ronald $\mathrm{C}$. and Kierzkowsk1, Henryk. NEIGHBORHOOD PRODUCTION STRUCTURES WITH APPLICATIONS TO THE THEORY OF INTERNATIONAL TRADE.

8410C Weller, Paul and Yano, Makoto. THE ROLE OF FUTURES MARKETS IN INTERNATIONAL TRADE: A GENERAL EỌUILIBRIUM APPROACH.

8411C Brecher, Richard A. and Bhagwati, Jagdish N. VOLUNTARY EXPORT RESTRICTIONS VERSUS IMPORT RESTRICTIONS: A WELFARE-THEORETIC COMPARISON . 
8412C Ethier, Wilfred J. ILLEGAL IMMIGRATION.

8413C Eaton, Jonathon and Gene M. Grossman. OPTIMAL TRADE AND INDUSTRIAL POLICY UNDER OLIGOPOLY.

8414C Wooton, Ian. PREFERENTIAL TRADING AGREEMENTS - A 3xn MODEL.

8415C Parkin, Michael. DISCRIMINATING BETWEEN KEYNESIAN AND CLASSICAL THEORIES OF THE BUSINESS CXCLE: JAPAN 1967-1982

8416C Deardorff, Alan V. FIRless FIRwoes: HOW PREFERENCES CAN INTERFERE WITH THE THEOREMS OF INTERNATIONAL TRADE.

8417C Greenwood, Jeremy. NONTRADED GOODS, THE TRADE BALANCE, AND THE BALANCE OF PAYMENTS.

8418C Blomqvist, Ake and Sharif Mohammad. CONTROLS, CORRUPTION, AND COMPETITIVE RENT-SEEKING IN LDCs.

8419C Grossman, Herschel I. POLICY, RATIONAL EXPECTATIONS, AND POSITIVE ECONOMIC ANALYSIS.

8420C Garber, Peter M. and Robert G. King. DEEP STRUCTURAL EXCAVATION? A CRITIOUE OF EULER EQUATION METHODS.

8421C Barro, Robert J. THE BEHAVIOR OF U.S. DEFICITS.

8422C Persson, Torsten and Lars E.0. Svensson. INTERNATIONAL BORROWING AND TIME-CONSISTENT FISCAL POLICY.

8423C Obstfeld Maurice. CAPITAL CONTROLS, THE DUAL EXCHANGE RATE, AND DEVALUATION.

8424C Kuhn, Peter. UNION PRODUCTIVITY EFFECTS AND ECONOMIC EFFICIENCY.

8425C Hamilton, Bob and John Whalley. TAX TREATMENT OF HOUSING IN A DYNAMIC SEOQUENCED GENERAL EỌUILIBRIUM MODEL.

3426C Hamilton, Bob, Sharif Mohammad, and John Whalley. RENT SEEKING AND THE NORTH-SOUTH TERMS OF TRADE.

8427C Adams, Charles and Jeremy Greenwood. DUAL EXCHANGE RATE SYSTEMS AND CAPITAL CONTROLS: AN INVESTIGATION.

8428 Loh, Choon Cheong and Michael R. Veall. A NOTE ON SOCIAL SECURITY AND PRIVATE SAVINGS IN SINGAPORE.

8429 Whalley, John. REGRESSION OR PROGRESSION: THE TAXING OUESTION OF INCIDENCE ANALYSIS.

8430 Kuhn, Peter. WAGES, EFFORT, AND INCENTIVE-COMPATIBILITY IN LIFE-CYCLE EMPLOYMENT CONTRACTS. 
8431 Greenwood, Jeremy and Kent P. Kimbrough. AN INVESTIGATION IN THE THEORY OF FOREIGN EXCHANGE CONTROLS.

8432 Greenwood, Jeremy and Kent P. Kimbrough. CAPITAL CONTROLS AND THE INTERNATIONAL TRANSMISSION OF FISCAL POLICY.

8433 Nguyen, Trien Trien and John Whalley. EOUILIBRIUM UNDER PRICE CONTROLS WITH ENDOGENOUS TRANSACTIONS COSTS.

8434 Adams, Charles and Russell S. Boyer. EFFICIENCY AND A SIMPLE MODEL OF EXCHANGE RATE DETERMINATION.

8435 Kuhn, Peter. UNIONS, ENTREPRENEURSHIP, AND EFFICIENCY. 